\title{
ETHICAL IMPLICATIONS OF DIGITAL ADVERTISING AUTOMATION: THE CASE OF PROGRAMMATIC ADVERTISING IN SPAIN
}

\author{
Implicaciones éticas de la automatización de la \\ publicidad digital: caso de la publicidad programática \\ en España
}

Inmaculada J. Martínez-Martínez, Juan-Miguel Aguado and Yannick Boeykens

Nota: Este artículo se puede leer en español en:

http://www.elprofesionaldelainformacion.com/contenidos/2017/mar/06_esp.pdf

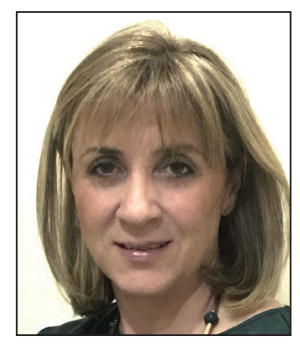

Inmaculada J. Martínez-Martínez has a PhD in Communication (Advertising) from the Complutense University in Madrid and an MA in Marketing at the Know How Business School. She is an assistant professor at the School of Communication and Information Studies, University of Murcia (Spain), where she teaches Advertising ecosystems. Her publications include "Mobile society: Culture, identity \& technology" (2008), "Mobilized: Women \& mobile in the information society" (2010); "Mobile communications: Towards a new media ecosystem" (2013) and "Emerging perspectives on the mobile content ecosystem" (2015). She is coordinating the R+D project "Mobile communications and personal data: Impact in media industry, advertising system, and users' perceptions" (CSO201347394-R) and "Mob Ad: The impact of mobile technology in strategic communication and advertising" (19451/PI/14) with researchers from Spain, UK, USA, Australia, and China.

http://orcid.org/0000-0003-3807-1325

inmartin@um.es

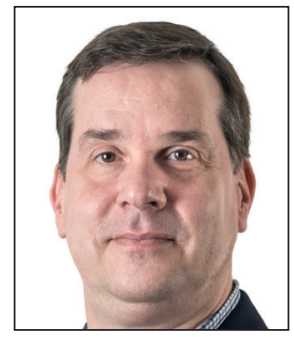

Juan-Miguel Aguado holds a PhD in Communication (Journalism) and an MA in Social research by the Polish Academy of Sciences (Warsaw). He is assistant professor of Communication Theory at the School of Communication and Information Studies, University of Murcia (Spain). His publications include "Mobile society: Culture, identity, and technology" (2008), "Mobilized: Women and mobile communication in the information society" (2010), "Technology and social complexity" (edited with Eva Buchinger and Bernard Scott, Editum, 2010), "Mobile communication: Towards a new media ecosystem" (Gedisa, 2013), and "Emerging perspectives on the mobile content ecosystem" (2015). Recent research activities include scientific consultancy in the following research projects: "Mobile communications and personal data: Impact in media industry, advertising system, and users' perceptions" (CSO2013-47394-R) and "Mob Ad: The impact of mobile technology in strategic communication and advertising" (19451/PI/14).

http://orcid.org/0000-0002-8922-3299

jmaguado@um.es

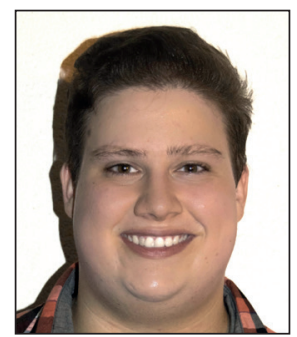

Yannick Boeykens is a junior researcher at the Social Communication, Culture, and Technology research group, University of Murcia, Spain (E053-07). He participates in the research project "Mob Ad: The impact of mobile technology in strategic communication and advertising" (19451/PI/14). He holds a BA in Advertising and Public Relations from the University of Murcia, an MA in Advertising, Marketing, and Social Media from the Barcelona Business School, and he has professional experience in advertising agencies at a regional level.

http://orcid.org/0000-0001-7232-247X

yannick.boeykens@gmail.com

Universidad de Murcia, Facultad de Comunicación y Documentación Campus de Espinardo, s/n. 30100 Murcia, Spain 


\begin{abstract}
Ineffective traditional advertising planning methods, the growing advertising saturation of digital media, and the disrupting influence of the digital players in the advertising sector have created a need for new methods and tools for advertising in today's ubiquitous Internet. Programmatic advertising is currently considered one of the most efficient forms of automation in the new online advertising environment and is excelling in major advertising markets like the US and United Kingdom. In Spain, however, there are still some important unaddressed questions regarding the level of implementation on a national and regional scale and the ethical implications derived from the implementation of this new technology. To address these points we have carried out qualitative research using a panel of experts with relevant background on the use of programmatic buying technology on a daily basis. The results stress the need for adapting capabilities in a rapidly evolving advertising sector, in which new technologies give rise to new complex processes with important ethical and reputational implications. We have identified a major contradiction between professionals' views and users' perceptions; the responsible use of these tools and the ability to identify the consequences of them appear to be a professional and functional challenge.
\end{abstract}

\title{
Keywords
}

Programmatic buying; Digital advertising; Digital media planning; Personal information; Big data; Ethics; Advertising ethics.

\section{Resumen}

La falta de eficacia de los métodos tradicionales de planificación en la publicidad tradicional, la creciente saturación publicitaria de los medios digitales y la influencia transformadora de los actores digitales en el sector han motivado la necesidad de desarrollar nuevos métodos y herramientas de publicidad para explotar de forma viable los recursos digitales que ofrece la Internet ubicua. La publicidad programática es actualmente considerada una de las formas más eficientes de automatización en este nuevo entorno de la publicidad digital, destacando su implantación en mercados publicitarios como los de EUA y Reino Unido. En el caso de España quedan aún importantes cuestiones por dilucidar, especialmente en lo relativo al grado de implementación tanto a escala nacional como regional y a las implicaciones éticas derivadas de la implementación de esta tecnología. Para arrojar luz sobre estos interrogantes hemos desarrollado una investigación cualitativa en un panel sobre una muestra de expertos con experiencia contrastada en el uso cotidiano profesional de esta tecnología. Los resultados subrayan la necesidad de capacidades de adaptación en un entorno rápidamente cambiante como el de la publicidad online, en el que las tecnologías posibilitan nuevos procesos con importantes implicaciones éticas y de reputación. A partir de la delimitación de una contradicción relevante entre las percepciones de los profesionales y los usuarios, el uso responsable de estas herramientas y la capacidad de observar las consecuencias derivadas de este uso se perfilan como un importante desafío profesional y funcional.

\section{Palabras clave}

Compra programática; Publicidad digital; Planificación de medios digital; Información personal; Ética del big data; Ética en publicidad.

Martínez-Martínez, Inmaculada J.; Aguado, Juan-Miguel; Boeykens, Yannick (2017). "Ethical implications of digital advertising automation: The case of programmatic advertising in Spain”. El profesional de la información, v. 26, n. 2, pp. 201-210

https://doi.org/10.3145/epi.2017.mar.06

\section{Introduction}

Advertising is a constantly evolving business environment that necessarily adapts to social and technological changes. The digital shift has deeply impacted the media ecosystem and consequently, so has the advertising logic (FeijóoGonzález; Gómez-Barroso; Martínez-Martínez, 2010). In a virtually infinite channel environment with an equally huge profiling potential, the challenge has shifted towards three dominant variables: price, scale, and efficiency. As in many other aspects in the online world, automation is the natural answer to that challenge (Busch, 2016). Programmatic trading ${ }^{1}$ appears to be the most relevant answer to the challenge of conciliating price, scale, and profiling power, integrating it into virtually any possible channel online:

"Nowadays, everything can be an advertising platform, we're not able to create a division between what is, and what is not, a communication channel" (Kelley; Sheehan; Jugenheimer, 2015).

While the adoption of programmatic trading is being widely implemented in developed markets such as the US or UK, the adoption figures in Spain are much more modest. Besides the obvious differences in the scale of these markets, figures show radical divergences:

- in the US, programmatic online display ad buying has already overtaken traditional ad spending, with approximately $\$ 10$ billion over 9.4 billion in revenue (IAB US, 2015); - in Spain, in 2016, only €36.9 million of the total $€ 259.6$ million online display advertising spent came from programmatic buying (IAB Spain, 2016).

Though much smaller in scale and slower in adoption, the trend points in the same direction as bigger markets do: average annual growth rate for semester 1, 2016 showed a $15.8 \%$ increase for standard display ads and a $25.6 \%$ for programmatic (IAB Spain, 2016).

The trend towards the automation of digital advertising involves consequences in multiple dimensions:

- the most evident example is the radical disruption of the digital media planning processes, with data management, new market configurations, and emerging new players as the main drivers; 
- these transformations come legal and ethical questions, especially regarding the use of technologies and procedures that involve monetizing personal and behavioral data (Gómez-Barroso; Feijóo-González, 2013).

\section{What is programmatic advertising and how does it differentiate from traditional methods?}

The term "programmatic advertising" refers to the advertising business that develops buying and selling processes via software based on automation. Programmatic buying and programmatic trading are thus used as synonyms. According to the $I A B^{\prime}$ 's white paper:

"Programmatic trading simplifies the buying and selling process bringing operational and pricing efficiency by digitally connecting the buyer and seller, enabling the programmatic purchase of ads via trading platforms" (IAB Europe, 2014).

It is software that automatically processes the sale of impressions (IAB UK, 2014), thus redefining the position of a media negotiator; it also involves the automation of other key aspects of ad trading, such as segmentation, profiling, and inventory management. The effective use of data is distinctive to programmatic advertising, allowing it to optimize pre-campaign planning, segmentation, and post-campaign analysis. In this digital context, the planning process substantially gains centrality and complexity (Stevens; Rau; Mclntyre, 2016).

The concept of programmatic trading (or buying) encompasses two different techniques: direct programmatic and real-time bidding (RTB). The second method, RTB, is perhaps the most widely known when talking about programmatic advertising. RTB consists of selling advertising spaces by auctioning them in real time (i.e. while the advertising space and the web content it is attached to are being loaded by the user). The highest bid in that fraction of a second wins the space and shows the specific advert for that user-leveraging the personal information about him or her collected by cookies and other tracking tools (Busch, 2016).

The programmatic trading process begins, thus, when a user connects to a specific webpage. In doing so, an information exchange between servers about both the user profile and the ad space availability takes place. If the advertising space is not reserved, the ad server connects to a supply-side platform or SSP (a platform that controls the publisher's ad inventory). The SSP sends the space availability to an ad exchange platform, that works like an ad marketplace with different types of products and potentially interested buyers. At the same time, the ad exchange plat- form operates as a meeting point for other platforms like DSP (demand-side platform), digital ad networks, or other ad exchange platforms. These platforms may provide more information about the user, more buyers or more inventories, enriching the bidding process. The winning DSP sends the information to the ad exchanger, who sends it to the SSP, placing the ad in the right place and moment to reach the user's eyes (Schäfer; Weiss, 2016).

While the adoption of programmatic trading has been widely implemented in developed markets such as the US or UK, the adoption figures in Spain are much more modest

According to programmatic ad spend reports (IAB Europe, 2014; IAB Spain, 2016), most programmatic buying uses a direct programmatic method over the RTB method due to the higher quality of inventory. However, as technology evolves, some experts believe the emergence of more complex Real Time Trading (RTT) will take the place of RTB in the near future (IAB UK, 2014).

As illustrated in figure 1, the data on the user profile and behavior are the main assets on both sides of the exchange. The emergence of data aggregators or DMPs (data management platforms) as third party players underlines the importance of user data to the very efficiency of the system.

The nature of data aggregation in regard to players in the programmatic ecosystem has important implications for both operational and ethical concerns (Watts, 2016). Programmatic practitioners use it to distinguish between firstparty data, second-party data. and third-party data.

- "First-party data are proprietary data that marketers and publishers have collected -with permission- and, therefore, own" (O'Hara, 2016). First-party data are high-quality data, because of their exclusive nature and proximity to the context of use and to the user/provider relationship, but they are also difficult and expensive to obtain.

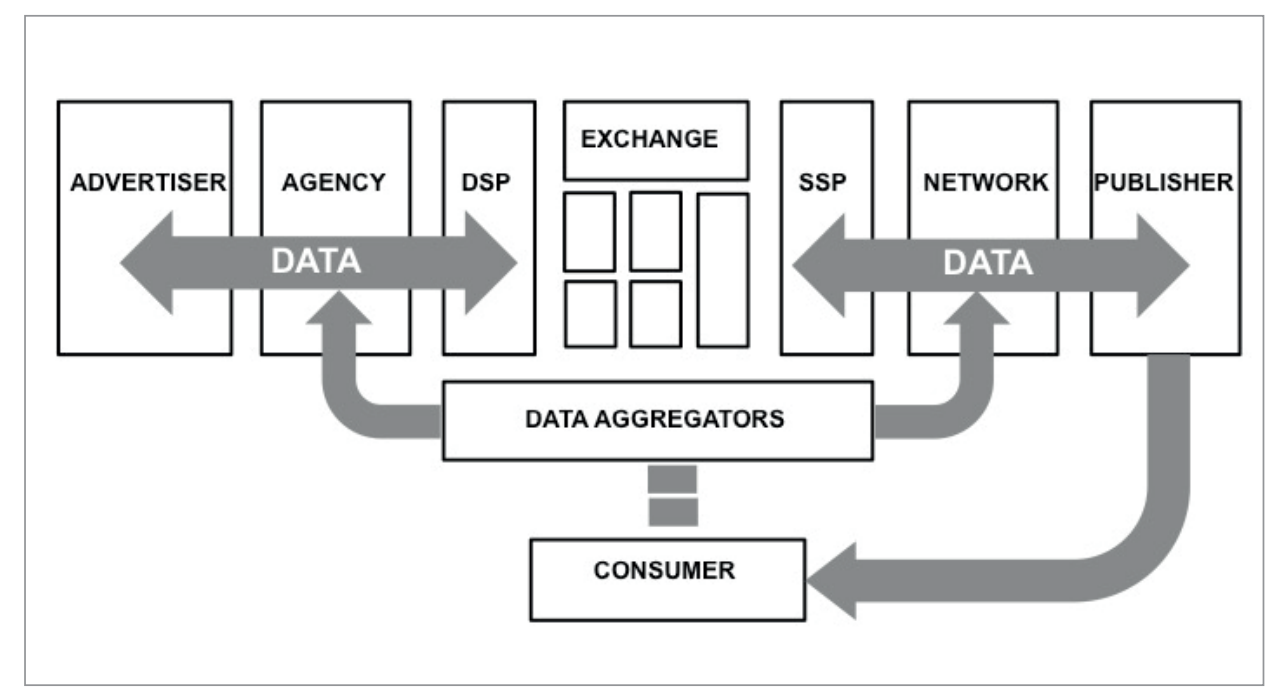

Figure 1. The programmatic advertising ecosystem (based on IAB, 2016) 
- Second party data are just first-party data exchanged between two players with coordinated interests.

- Third-party data are syndicated data harvested by specialized data aggregators (DMPs) which are then made publicly available to buyers.

As illustrated in figure 2, the availability of data in the programmatic trading ecosystem is inversely proportional to data quality (Stillman; Letang, 2015) and directly proportional to their problematic nature. The data with a larger presence in the market -third party data- are precisely those with less quality and the ones that are more legally and ethically sensitive (Ponemon Institute, 2016).

\section{Ethical implications of data driven advertising}

The irruption of new digital processes and players in the late 2000's has altered ethical challenges in advertising, traditionally

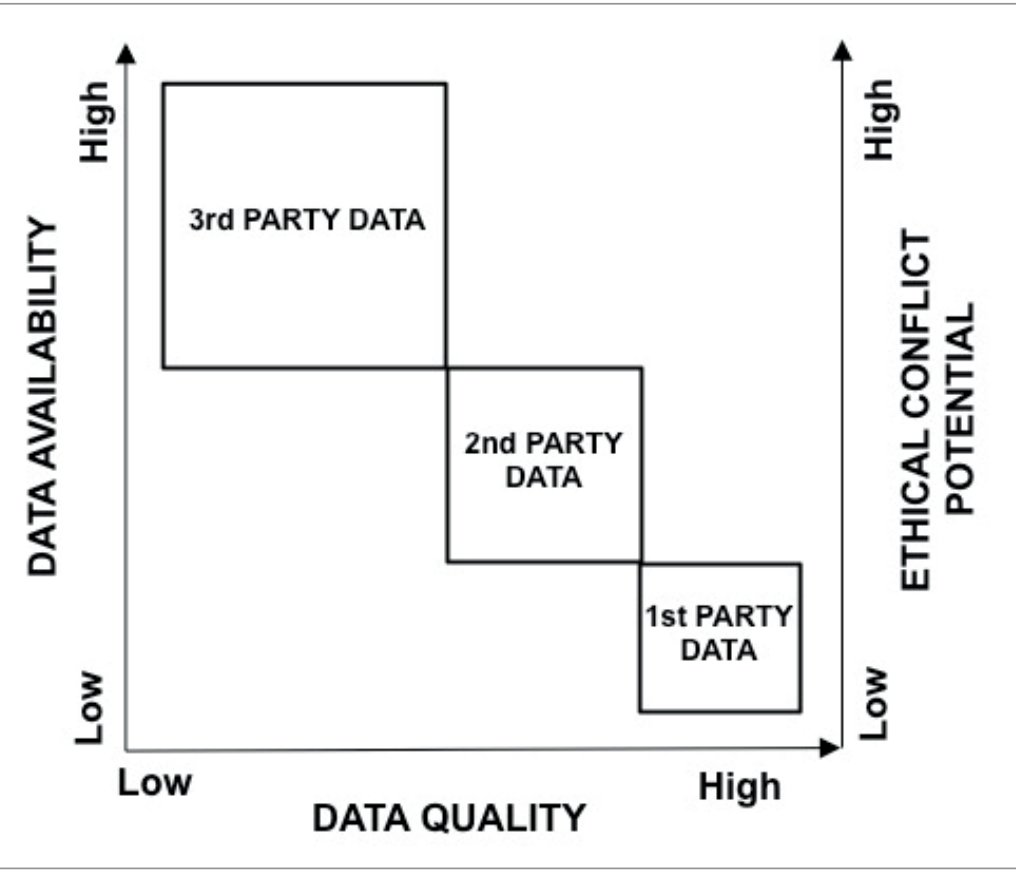

Figure 2. $1^{\text {st }}, 2^{\text {nd }}$ and $3^{\text {rd }}$ party data characterization (based on O'Hara, 2016) related to institutional control, trustworthiness, psychological influence, scale of effects, and cultural impact (Drumwright; Murphy, 2009). Along with digitization, the adoption of technologies addressing the automation of data collection and management introduces into advertising a whole new range of ethical problems and challenges, related to the kind of problems discussed in market research ethics as well as in the broader debate on the ethical implications of big data (Nunan; Di-Domenico, 2013).

Connecting professional perceptions about ethical implications to direct knowledge of barriers and drivers in the implementation of programmatic advertising is an unexplored area

Programmatic trading is a form of data driven -or big datatechnologies, for example instrumental applications that take advantage of massive or intensive data management. In the case considered here, these are data about users' digital profiles and online behavior. Programmatic advertising is thus part of what Acquisti (2009) and others (Gómez-Barroso; Feijóo-González, 2013) have called the 'personal information economy', where the capacity to gather, process, manage, and effectively use personal information becomes a core economic asset.

In the process of programmatic trading:

"data management platforms (DMPs) help produce a single, coherent set of metrics that can be used to inteIligently describe, target, and track a consumer audience across all channels and devices. DMPs work hand-in-glove with demand-side platforms (DSPs) to precisely deliver advertisements to the right consumer, at the right time, and in the right context" (Watts, 2016).

Data fulfills a threefold function in this circumstance: to identify, target, and deliver ads (IAB UK, 2014; Stillman; Letang, 2015). In the first case, data are integrated into profiles, thereby allowing the pairing of specific users with available impressions. Targeting data are central to determining the value of a given user for a given impression according to campaign parameters. Once the trade is made, delivering data sets facilitates channeling the ad to the right place in the right moment. The kind of data DMPs deal with is not limited to specific user behavior in a concrete brand site. Data include any kind of profile resource available via tracking tools, including social data, email, subscriptions, device information (such as location), telecom data, and online transaction data (Stillman; Letang, 2015). The benefits of integrating data management into the trading process are diverse and include (Busch, 2016):

- greater efficiency,

- enhanced targeting, and/or

- optimized campaigns.

But such intensive use of personal data also raises concerns about privacy and security (Tucker, 2012; Gómez-Barroso; Feijóo-González, 2013).

Although privacy seems to be top among users' concerns about digital life (Orange, 2014; Telefónica, 2016), online behavior does not tend to mirror these concerns (Rainie; Duggan, 2016). This so-called 'privacy paradox' is often related to behavioral variables -such as risk perception or perceived benefits (Gómez-Barroso; Feijóo-González, 2013)-. However, the nature of the market, the level of transparency, and the relative position of consumers in the process have influence (Schwaig et al., 2013; Rainie; Duggan, 2016).

While other data driven services, like eHealth or certain recommendation systems (e.g. Netflix or Amazon), depend on first or second-data party management, the importance of 
third-party data players is distinctive to the programmatic ecosystem, and thus to advertising. Third-party data players are often questioned for their security holes and lack of response in relation privacy issues, due to the problems of insuring data traceability (Ponemon Institute, 2016). Because of the prevalence of third-party data players, the process of programmatic trading remains mostly unnoticed to users. This challenges most usual strategies in addressing digital privacy concerns, such as permission request and informed decision-making (Martínez-Martínez; Aguado, 2014). The combination of a lack of available knowledge and growing user sensitivity might involve supplementary reputational challenges for the transformation of the advertising industry (Watts, 2016).

Programmatic trading is a form of data (or big data) driven technology, for example instrumental applications that take advantage of massive or intensive data management

\section{An approach to programmatic advertising in Spain: Assessing penetration and ethical implications}

Compared to traditional methods, programmatic buying is a more efficient and effective way to plan online media (IAB Europe, 2014). According to smartphone and Internet penetration data (Fundación Telefónica, 2016), Spain is a mature market with relevant potential for technology-based innovations, especially in the media environment. As in other European countries, ad spending is increasingly shifting to digital and mobile standards (IAB Spain, 2016; IAB UK, 2016). This research seeks to assess the professionals' view of the current level of implementation of programmatic advertising in Spain, both in a regional and national scale, considering the challenges, barriers, and opportunities it brings with it. Amongst them, this research focuses on the cultural change in the advertising ethics derived from bringing massive personal data management to the core of advertising dynamics through the implementation of programmatic tools and procedures.

Recent studies in Spain illustrate the prevalence of traditional media planning methods $(86.14 \%)$ over more innovative methods like programmatic buying (13.86\%) (IAB Spain, 2016). Comparing these numbers to recent US studies clearly shows the scale of difference: In 2015 , only $58 \%$ of online media planning was handled by traditional methods, and $42 \%$ by programmatic buying (IAB US, 2015).

This apparently contradictory landscape demands a closer focus in order to understand the implementation of the programmatic technology on a national and regional scale. To do that, we have focused on the perceptions of relevant professional players with direct knowledge of the market and the state of the art in technology. Though there is a wide range of available research on the ethical and legal problems derived from personal information and big data driven user profiling (Pavlou, 2011; Tucker, 2012), the interest in exploring these implications in the specific case of data driven advertising is still incipient. Such emerging literature focuses mostly on users' perceptions (Schwaig et al., 2013; Watts, 2016). Connecting professional perceptions on the ethical implications to the direct knowledge of barriers and drivers in the penetration of programmatic advertising is an unexplored area that deserves to be considered.

We utilized the Delphi method (Brady, 2015) to conduct an expert panel, and we included additional in-depth interviews to obtain more complex answers to key issues. The panel sample was comprised of 13 life-long advertising professionals who were directly involved in the process of programmatic advertising implementation in Spain, both in national (7 experts) and regional arenas (6 experts), some of them being part of a study panel on programmatic buying organized by IAB Spain (see table 1). Respondents were selected according to balanced opportunity/convenience criteria, fulfilling in all cases the prerequisites of having a minimum of 5-years of direct experience in the field, along with specialized managerial experience. All experts answered a two-wave questionnaire about the implantation and ethical problems of programmatic advertising, plus a set of in-depth interviews in order to specifically address more complex or relevant issues arising from the panel.

The nature of data aggregation with regard to players in the programmatic ecosystem has important implications for operational and ethical concerns

The questionnaire was structured into six open questions designed to consolidate answers into both consensus and dissent in the sample throughout the two waves (see Table 2). Questions dealt with three main aspects:

- the level of penetration;

- ethical challenges; and

- the future of programmatic technology.

After the first wave the consensus and dissent resulted in a modified questionnaire. The second wave addressed specific dilemmas emerging from different positions, such as characteristics of private marketplaces, different arguments about whether the level of users' information on digital privacy was a relevant ethical variable, or the future role of

Table 1. Programmatic advertising players represented in the sample

\begin{tabular}{|l|l|}
\hline \multicolumn{1}{|c|}{ National-scale players } & \multicolumn{1}{c|}{ Regional-scale players } \\
\hline MediaMath & Germinal Comunicación \\
\hline Affiperf & Portavoz \\
\hline Zodiak Advertising & Avante \\
\hline PAN & Vocento \\
\hline Mobext & Bee Social \\
\hline Prisa & Acceso \\
\hline Weborama & \\
\hline
\end{tabular}


Table 2. Questionnaire and aims of discussion

\begin{tabular}{|c|c|}
\hline Question & Aim of discussion \\
\hline $\begin{array}{l}\text { Q1: Explain the reasons why agencies are still spending more money in traditio- } \\
\text { nal methods. Do you think we are talking about an established technology or is } \\
\text { this new method still too young? }\end{array}$ & Perceptions on the level of implantation \\
\hline $\begin{array}{l}\text { Q2: Explain the possible reasons why most agencies still prefer more traditional } \\
\text { methods to more effective and innovative ways of media planning on a regional } \\
\text { scale. Or, if you do not agree with this statement, why do you think that regional } \\
\text { campaigns do resort to programmatic buying? }\end{array}$ & Differences in implantation at a regional scale \\
\hline $\begin{array}{l}\text { Q3: Give a detailed explanation about your opinion related to open and private } \\
\text { marketplaces in programmatic trading. What are the pros and cons and the ethi- } \\
\text { cal consequences related to each of these types of market? }\end{array}$ & \multirow{3}{*}{$\begin{array}{l}\text { Implications of open and private marketplaces } \\
\text { / Ethical implications of programmatic trading and the role of } \\
\text { third party data }\end{array}$} \\
\hline $\begin{array}{l}\text { Q4: What do you think are the consequences of dividing the advertising mar- } \\
\text { ket in two separate segments? Do you think every advertiser should be allowed } \\
\text { access to all available spaces? Does the separation have consequences for the } \\
\text { final user? }\end{array}$ & \\
\hline $\begin{array}{l}\text { Q5: When a advertising campaign uses programmatic buying, it resorts to in- } \\
\text { tensive data driven strategies. To what extent do you think it is ethical to use } \\
\text { all available information on users to plan and create an advertising campaign? } \\
\text { What do you think about buying third party data? }\end{array}$ & \\
\hline $\begin{array}{l}\text { Q6: What is your professional perception about the future of programmatic in } \\
\text { the upcoming evolution of advertising industries and it relation to ethical/legal } \\
\text { challenges. }\end{array}$ & $\begin{array}{l}\text { Perceptions on the future developments and ethical challenges } \\
\text { of programmatic advertising }\end{array}$ \\
\hline
\end{tabular}

mobile and cross-media programmatic technology. These and other aspects were completed by specific in-depth interviews with the experts.

\section{Results}

Taking into account questionnaires and complementing interviews, we have processed answers along the opposite variables of consensus and variety (dissent). Percentages are illustrative to the level of similarity in the terms and arguments used by experts. Following the questions explained above, we summarize the results as follows:

\section{Q1: Assessing the level of implementation and the perceived reasons for it}

Experts showed a wide level of agreement when considering the implementation of programmatic advertising technology in Spain as incipient and tentative. A majority of answers (36\%) pointed at publishers as the main cause to that. They blamed media for being especially reluctant to adopt new methods in advertising. According to one of the experts, the new method "scares the media. They are afraid to lose business, to lose existing advertisers or to lose money".

Fear of innovation was repeatedly noted as a featuring aspect of the state of programmatic trading in Spain (27\%), together with the lack of appropriate training (18\%), and experience (18\%). The consciousness of an underdeveloped early bird technology was more marked in the case or the regional players in the sample. Considered together, the argued reasons for that incipient state of the art contributed to outline a picture of a highly conservative market with players castled in well-know procedures and strategies. Nonetheless, when looking at more mature markets, experts felt confident about the future of programmatic advertising in Spain.

\section{Q2: Differences in implantation at a regional scale}

Having in mind reports about a larger proportion of national-scaled programmatic campaigns (IAB US, 2016), we hypothesized about the lack of know-how and up-to-date specialization in smaller advertising agencies being a relevant cause for the low implementation of programmatic technology at a regional scale. Experts unanimously pointed at regional advertisers as the main burden to the application of new methods in regional advertising. Reasons, however, varied in regard to the different regional players.

- In the case of advertisers, experts point to an outdated mentality underlying their reluctance to change (80\%).

- In the case of agencies and advertisers, financial crisis and budgetary restrictions were also understood to play a role (32\%).

To a lesser extent, some experts mentioned concerns about publishers' and advertisers' mistrust towards new technologies and processes (20\%). Finally, the lack of attitude and a certain kind of laziness were identified as the reason for regional agencies to keep the technological status quo (48\%):

"Some of the agencies don't offer more innovative ways of media planning to their clients because they don't want to be bothered with new ways of doing things. Using more established methods means less work for them".

Even though experts accepted a clearly lower penetration rate for programmatic methods at a regional scale, causes were identified with market structure -mainly lack of demand and a subsequent lack of will to update products or services. Apart from its obvious implications in the industry evolution, this view also concerns the level of consciousness in the sector about the ethical implications derived from a procedure -data exploitation- that seemed to be virtually absent in most regional agendas. 


\section{Q3 and Q4: About the implications of open and priva- te marketplaces}

Third and fourth study propositions were consecutive and correlated. They basically looked into the perceived efficiency of the division between open and private marketplaces. In the first place we inquired about the characteristics of open and private marketplaces in terms of advantages and burdens. Secondly, we wondered about the functional and ethical consequences of that differentiation.

The first round did not offer consensus amongst the panel members. Each professional had a different opinion on the pros and cons of open and private marketplaces. There was, however, a certain level of coincidence around characterizing private marketplaces as a secure and reliable space. The second round, however, obtained significant agreement on two different issues:

- Experts widely believed (86\%) that private marketplaces were necessary to give the publishers a secure, reliable, and quality workspace for important advertisers, and at the same time,

- they did not seem to appreciate important ethical consequences of that differentiation, apart from the ones commonly derived from market dynamics.

When asked about the possibility that private marketplaces could discriminate against smaller advertisers and offer more advantages to bigger companies with more financial resources, panelists split into two opposite perceptions:

- the first group of experts related to national-scale players did not believe PMPs discriminated against smaller players;

- experts from regional players believed that budgetary problems and the size of regional companies operated as entry barriers to PMPs, and contributed to the burden of the implantation of the technology at a regional scale or to facilitate the expansion of national-scale players to local markets.

In addition to that, the personal interviews also showed some insecurity about PMPs. One of the interviewees, for instance, explained that having a global market open to all advertisers would be more adequate, despite understanding the necessity of having private marketplaces.

The importance given by the panelists to PMPs also had implications as to the ethical challenges of programmatic trading: transparency and reliability of transactions inside PMPs may involve assumptions about the nature of data and user knowledge on privacy issues different from more chaotic and opaque open marketplaces.

\section{Q5: Ethical implications of programmatic trading and the role of third party data}

As in other data driven processes, programmatic advertising involves intensive use of users' personal data. These data are collected by different kinds of increasingly specialized players. The automated and highly specialized nature of data exploitation in programmatic advertising gives rise to important concerns about the ethical aspects in the processes of managing and trading these data, as well as about the users' level of information. The incipient implantation of programmatic technology and the adaptation process this involves for advertising professionals and companies also influences these ethical concerns.

From the perspective of the professionals involved, ethical aspects of programmatic advertising refer mainly to two different perspectives:

- In first perspective: Is it ethical, or not, to freely dispose of intensive user data regardless of the origin and context of these data sets?

- Is it possible, or not, given the level of the user's knowledge about procedures -and even to a certain capacity the ability to decide- to eliminate privacy related ethical concerns.

At this point it is important to take into account that the prevailing strategies to dealing with privacy concerns in e-marketing and digital advertising address these latter aspects, enhancing user information about privacy related issues, transparency about the uses of personal data and user permission request in concrete procedures (Gómez-Barroso; Feijóo-González, 2013). The perceived attractiveness or utility of a given ad are resources given in exchange for personal data disclosure (Martínez-Martínez; Aguado, 2014).

The data with a larger presence in the market -third party data- are of lower quality and also more legally and ethically sensitive

The question about the ethical nature of freely disposing of intensive user data generated dissent in the panel sample. Though a majority of the experts were prone to admit the use of personal data was an ethical practice in programmatic advertising -under the user's consent-, there was a clear lack of agreement when considering whether this user was given enough information to understand what he or she is accepting. Seeking to clarify positions, the second round with experts demanded positioning on two dissenting propositions:

Proposition 1: There is no ethical implication in using all available user information on the Internet because users have enough information to understand whether to accept cookies or other data collection methods.

Proposition 2: Users do not have sufficiently clear and reliable mechanisms to really understand what privacy on the Internet means. It would only be ethical when they have enough clear and reliable information, and if they have given their consent.

In this case experts showed a wider consensus, with $75 \%$ of the sample stating agreement with proposition 1 and $25 \%$ with proposition 2 . The difference was somehow slightly less significant in the case of experts from national players, to which conceiving the disposal of user data as a fully ethical procedure was accepted by barely $60 \%$ of respondents. This is, to our view, an aspect to remark upon, since national 
scale players are involved in a more advanced level of implementation of programmatic technology, and they develop their strategies more frequently in private marketplaces.

Interviews with experts reproduced these opposed views in similar terms. One of the respondents explained the necessity of creating new and more precise laws to make clear what kind of information tracking methods, like cookies, might run. However, the clearly dominant position was to accept arguments about responsible well-informed users freely choosing options.

Beyond the common general practices of privacy and security, participants in the experts' panel displayed a low perception of ethical conflicts and challenges in real-life programmatic trading development

According to that view, professionals consider third party data as a valuable and necessary resource, obviating any ethical challenge related to players specialized in gathering users' data from different secondary sources and trading them. For almost all experts third party data are a necessary condition to create reliable and effective advertising strategies, because relying solely on first or second party data would be too costly for most companies, and much less effective.

\section{Q6: Perceptions on the future developments and ethical challenges of programmatic advertising}

To trigger the debate on the future developments of data driven advertising we confronted experts with some US specialists' opinions stating the dying nature of programmatic trading. Most of them were shocked. The majority of professionals believed programmatic technology will be able to adapt to changes in the market, in the industry, or even in the technology standards. When asked to concretely characterize these changes, they pointed in two directions: mobile technologies and cross-media environments.

There was unanimous agreement about the potential for future developments in cross-media environments, where data and impressions from different platforms and media can be coordinated. Also, some experts considered mobile technologies and the capacity to manage ubiquitous information as a promising path for the future. More in-depth conversations in interviews showed a specific interest in exploring a combination of developing trends in digital advertising, such as native advertising. Panelists showed they were excited about upcoming technological or procedural revolutions, and they generally shared an optimistic view focused on technology and efficiency. How regulation or social uses on privacy may affect that future throw no shadow in the professionals' view of future data driven advertising. In fact, when summarizing in keywords their view on programmatic trading, the dominant terms were, in this order: "automatization", "future", "possibilities", "opportunities", "technology", and "maximization".

\section{Conclusions}

Programmatic advertising is a form of data driven technology that is contributing to the effective transformation of tools and strategies in the current advertising ecosystem. In mature markets, like the USA or UK, programmatic is already leading digital advertising spending growth. In Spain, however-despite having the fertile ground of a technologically advanced consumer market-, development is still at an early stage. The penetration of this new technology involves two related kinds of challenges:

- market structure transformations, and

- coping with legal/ethical concerns.

The latter concerns are part of a broader debate on digital privacy issues and data driven technologies. In a sense, digitization and automation introduces into advertising a whole new range of ethical problems and challenges and a new culture, closer to information management related quandaries in marketing ethics (Nunan; Di-Domenico, 2013).

As in other digital data driven services, programmatic advertising entails consequences for the market structure, especially in integrating smaller regional scaled players. Updating players' mind structures to the new data-driven game seems a relevant burden to experts dealing with programmatic developments in Spain. Reluctances appear to be related to budgetary restrictions, low level of knowledge, and a mistrust of new technologies. Fear of innovation and conservative attitudes to new strategies and products are more evident in regional arenas, where the prevailing role of private marketplaces is perceived to favor bigger centralized players. Despite this, they perceive deep structural challenges to come, experts' attitudes towards programmatic trading is optimistic and they tend to have a promising view focused on technology as a guarantee of efficiency. This guarantee seems to counterweight all burdens raised in the discussions, including those related to ethical issues.

Despite the perceived deep structural challenges to come, experts' attitudes towards programmatic trading was optimistic

Dealing as it does with massive automated personal data processing, the legal, procedural, and ethical aspects involved in the implantation of programmatic advertising are relevant in its future development. However, experts are considering the growing concern about misusing personal information for unknown or unwanted purposes, as a private choice problem or as a legal issue. Privacy related problems in programmatic advertising (such as intensive retargeting, spamming, or data reselling) are tackled as general issues. The dichotomy between service improvement and extensive surveillance that accompanies data driven advertising (Christiansen, 2011) was obviated in the considerations of the interviewed experts. And the dilemma about the limits and extent of personal data management was mostly restrained to legal and functional criteria. 
Research results showed a prevailing third-person-oriented perception of the problem in professionals' views, prone to attribute new derived from programmatic procedures ethical responsibilities to market dynamics, regulators, policy makers, and the users themselves. Accordingly, interviews with experts brought out a professional version of that same privacy paradox: while there was agreement about the general importance of privacy issues, these were effectively pushed into the background as a legal problem or as a matter of the informed user's sovereignty. In clear contrast with existing research on users' perceptions and with policy making guidelines, participants in the experts' panel show a low perception of ethical conflicts and challenges in the reallife programmatic trading development, and they tended to conceive of personal data as a valuable economic asset rather than as a sensitive resource. This view raises concerns about the commitment of the industry in the protection of privacy within data driven advertising processes. Further research should enrich and contrast this view in order to include it into privacy related policy-making discussions.

Fear of innovation was repeatedly noted as an aspect of the state of programmatic trading in Spain, together with the lack of appropriate training and experience

\section{Notes}

1. In this paper we indistinctly use the terms programmatic advertising, programmatic buying, and programmatic trading, with the understanding that programmatic advertising is a kind of digital advertising differentiated by the automation of trading and/or buying procedures, involving the use of data driven technologies (Busch, 2016; Watts, 2016).

\section{Acknowledgements}

The research results presented in this paper are part of two coordinated projects: Mobile media \& personal data: Impact in media industries, advertising system and users' perception, funded by the Spanish Ministry of Economy and Competitiveness (CSO2013-47394-R) and Mob Ad: Impact of mobile technologies in strategic and commercial communication funded by the Regional Agency for Science and Technology - Seneca Foundation (19451/PI/14).

\section{References}

Acquisti, Alessandro (2009). "Nudging privacy: The behavioral economics of personal information". IEEE security \& privacy, v. 7, n. 6, pp. 82-85.

http://www.heinz.cmu.edu/ acquisti/papers/acquisti-privacynudging.pdf

Brady, Shane R. (2015). "Utilizing and adapting the Delphi method for use in qualitative research". International journal of qualitative methods, v. 14, n. 5, pp. 8-14

https://doi.org/10.1177/1609406915621381

Busch, Oliver (2016). "The programmatic advertising principle". In: Busch, Oliver (ed.). Programmatic advertising. Berlin: Springer International Publishing, pp. 3-15. ISBN: 978 3319250236
Christiansen, Linda (2011). "Personal privacy and internet marketing: An impossible conflict or a marriage made in heaven?". Business horizons, v. 54, n. 6, pp. 509-514.

https://goo.gl/QAMJ8b

http://dx.doi.org/10.1016/j.bushor.2011.06.002

Drumwright, Minette E.; Murphy, Patrick E. (2009). "The current state of advertising ethics: Industry and academic perspectives". Journal of advertising, v. 38, n. 1, pp. 83-108. https://goo.gl/IQzGT8

http://dx.doi.org/10.2753/JOA0091-3367380106

Feijóo-González, Claudio; Gómez-Barroso, José-Luis; Martínez-Martínez, Inmaculada J. (2010). “Nuevas vías para la comunicación empresarial: publicidad en el móvil". El profesional de la información, v. 19, n. 2, pp. 140-148. https://doi.org/10.3145/epi.2010.mar.04

Fundación Telefónica (2016). Informe sociedad de la información en España, 2015. Madrid: Fundación TelefónicaAriel. ISBN: 9788408152798

Gómez-Barroso, José-Luis; Feijóo-González, Claudio (2013). "Información personal: la nueva moneda de la economía digital”. El profesional de la información, v. 22, n. 4, pp. 290-29. https://doi.org/10.3145/epi.2013.jul.03

IAB (2016). Data driven advertising. IAB. http://www.iab.net/data

$I A B$ Europe (2014). Programmatic trading. An IAB Europe whitepaper. IAB Europe.

http://www.iabeurope.eu/files/8614/0776/0957/IAB_Europe_ Programmatic_Trading_White_Paper_July_2014_v2.pdf

IAB Spain (2014). Libro blanco de la compra programática. IAB Spain.

http://www.iabspain.net/wp-content/uploads/downloads/2014/09/ Libro-blanco-de-Compra-Program\%C3\%A1tica-y-RTB.pdf

IAB Spain (2016). Inversión en medios digitales. Resultados S1 2016. PWC; IAB Spain.

http://www.iabspain.net/wp-content/uploads/downloads/2016/09/ Estudio_Inversion_Medios_Digitales_S120161.pdf

IAB UK (2014). The programmatic handbook. labuk.net.

http://www.iabuk.net/sites/default/files/The\%20 Programmatic\%20Handbook.pdf

IAB UK (2016). Ad spend on mobile display overtakes PC for first time. labuk.net.

https://www.iabuk.net/about/press/archive/adspend-onmobile-display-overtakes-pc-for-first-time

$I A B$ US (2016). IAB/PWC digital advertising revenue report Q1 2016. IAB.

http://www.iab.com/news/first-quarter-u-s-internet-adrevenues-hit-record-setting-high-nearly-16-billion-according-iab

IAB US (2015). US programmatic ad revenues totaled \$10.1 billion in 2014, according to first-ever IAB programmatic revenue report. IAB, 20 July.

https://www.iab.com/news/u-s-programmatic-display-adrevenues-totaled-10-1-billion-in-2014-according-to-first-everiab-programmatic-revenue-report

Kelley, Larry; Sheehan, Kim; Jugenheimer, Donald W. (2015). Advertising media planning: A brand management 
approach. Routledge. ISBN: 9780765640901

Martínez-Martínez, Inmaculada J.; Aguado, Juan-Miguel (2014). "Publicidad móvil: impacto presente y futuro en el ecosistema del contenido digital". In Revista de la Asociación Española de Investigación en Comunicación (Raeic), v. 1, n. 1, pp. 76-85.

http://www.novosmedios.org/revista/index.php/AEICp/ article/view/38

Nunan, Daniel; Di-Domenico, Maria-Laura (2013). “Market research \& the ethics of big data". International journal of market research, v. 55, n. 4, pp. 505-520.

https://doi.org/10.2501/IJMR-2013-015

O’Hara, Chris (2016). “Data triangulation: How second-party data will eat the digital world". AdExchanger, January 25. http://adexchanger.com/data-driven-thinking/datatriangulation-how-second-party-data-will-eat-the-digital-world

Orange (2014). The future of digital trust. A European study on the nature of consumer trust and personal data.

http://www.orange.com/en/content/download/21358/412063/ version/5/file/Orange+Future+of+Digital+Trust+Report.pdf

Pavlou, Paul A. (2011). "State of the information privacy literature: Where are we now and where should we go?". MIS quarterly, v. 35, n. 4, pp. 977-988.

https://papers.ssrn.com/sol3/papers2.cfm?abstract $i d=2369375$

Ponemon Institute (2016). Data risk in the third-party ecosystem. Ponemon Institute 2016 Research report.

http://www.buckleysandler.com/uploads/1082/doc/Data_ Risk_in_the_Third_Party_Ecosystem_BuckleySandler_LLP_ and_Treliant_R....pdf

Rainie, Lee; Duggan, Maeve (2016). Privacy and informa- tion sharing. Pew Reseach Center in Internet, Science and Technology.

http://www.pewinternet.org/files/2016/01/PI_2016.01.14 Privacy-and-Info-Sharing_FINAL.pdf

Schäfer, Arno; Weiss, Oliver (2016). "Understanding demand-side-platforms". In: Programmatic advertising. Berlin, Springer International Publishing, pp. 75-86. ISBN: 978 3319250236

https://doi.org/10.1007/978-3-319-25023-6_6

Schwaig, Kathy S.; Segars, Albert H.; Grover, Varun; Fiedler, Kirk D. (2013). "A model of consumers' perceptions of the invasion of information privacy". Information \& management, v. 50, n. 1, pp. 1-12.

https://doi.org/10.1016/j.im.2012.11.002

Stevens, Andy; Rau, Andreas; Mclntyre, Matthew (2016). "Integrated campaign planning in a programmatic world". In: Programmatic advertising. Berlin: Springer International Publishing, pp. 193-210. ISBN: 9783319250236 https://doi.org/10.1007/978-3-319-25023-6_16

Stillman, Luke; Letang, Vincent (2015). Programmatic 2015. The path forward. Magna Global.

http://www.cadreon.com/wp-content/uploads/2015/10/ Spring-2015-Programmatic-FINAL.pdf

Tucker, Catherine E. (2012). "The economics of advertising and privacy". International journal of industrial organization, v. 30, n. 3, pp. 326-329.

http://cetucker.scripts.mit.edu/docs/econ_summary_2011.pdf https://doi.org/10.1016/j.ijindorg.2011.11.004

Watts, Mack (2016). Programmatic advertising: Shaping consumer behavior or invading consumer privacy? Undergraduate distinction tesis. Ohio State University. http://kb.osu.edu/dspace/handle/1811/76764

\section{Da visibilidad a tu trabajo depositándolo en e-LIS, el mayor repositorio internacional sobre biblioteconomía, documentación y comunicación}

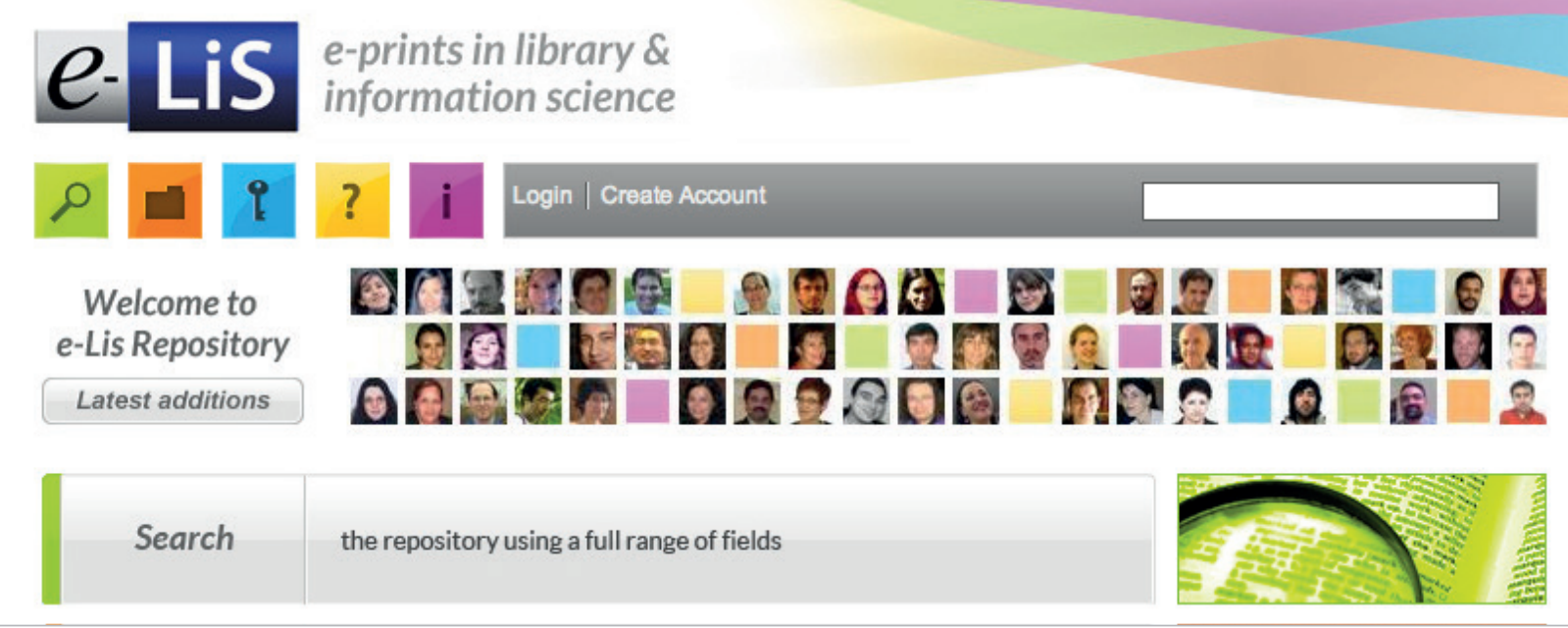

http://eprints.rclis.org 